\title{
The Roles Of Problem-Based Learning (PBL) Improving The Independence Andthe Successof Prospective Teachers Learning
}

\author{
Taufik Rahman \\ Departmen of Biology Education UPI \\ taufikrahman245@yahoo.com
}

\begin{abstract}
This study explored the roles of PBL to the independence and the success of prospective teacher learning. The problem of this research was how the role of PBL in increasing the independence and the success of prospective teacher learning. The research employed a descriptive method as it aimed at identifying teachers' independence. The research subject covering one grade biology prospective teachers at semester 6 that take a course called "Planning Lessons". The results of this research showed that the independence of prospective teacher was improving and so is the learning success. Therefore, it is recommended to use PBL in developing students' independence
\end{abstract}

Keywords-PBL; independence; learning success.

\section{INTRODUCTION}

Problem Based Learning (PBL) is a learning model that requires learners to be able to solve the problem. Problems are applied in problem-based learning is unstructured problems (ill-structured) and open (open-ended). Structured problems the answer can be found in textbooks, whereas unstructured problems generally: do not provided sufficient information to the solution, additional information is required, and may include some alternative solutions. Problem based learning make students resolve problems from different angles or in different ways, so that learners can be considered as the architect responsible for the problem solution $[1 ; 8]$. Research on PBL and its impact on learning outcomes has been widely described $[1 ; 2 ; 8]$, but still needs to be developed. In line with this, the role of PBL against independence and learning success was important to be disclosed.

Being independent learners is important for all, including prospective teachers. Being independent is necessary in life to live without the help of others. In the schools learners were often less triggered to be able to learn independently. Learning is not just transferring knowledge from teacher or lecturer to students. Learners did not have many opportunities to learn to solve living problems. This can have an impact on the lack of ability of learners in solving problems independently.

Students are required to have independence in various ways, especially in solving the problem. Independent learning can be defined as a process by which an individual develops learning initiative, with or without the help of others; diagnose their own learning needs, formulating learning goals, identifying learning resources that it can use, select and implement learning strategies, and evaluating learning outcomes $[3 ; 7]$.

Lack of opportunities for learners to learn independently can result in low ability and learning outcomes of students. It can be due to the lack of trained students learn independently impact on the lack of cognitive, affective, and psychomotor. Learners will likely be less able to do high-level thinking, but just able to thinking levels low. Higher level thinking covers application, analysis, synthesis, evaluation, and creation. Low level thinking includes recall and comprehension. Low level thinking is not enough to be able to solve the problems of life. Thus they need to build high-level thinking skills through PBL in order smart in problem solving [5].

One of important learning for prospective teachers, associated with problem solving, can be seen from his ability in designing Lesson Plans (LP). Designing lesson plan is one of a complex problem. Teachers or prospective teachers are demanded to solve the problem of how to design learning so that lessons can be easily understood by learners. They have to think how objectives, materials, ways of learning, work sheets and evaluation should be formulated. They have also to think what models, approaches, methods, media, learning resources which are suitable for use, and how to apply them in learning by taking into account various situations and conditions of learners and schools[9].Observations in the field, the ability to make the correct lesson plan not fully overpowered by many teacher, although it should be it already owned properly by the teacher independently.

The problem raised in this research, how the role of PBL against the independence and learning success of prospective teachers? The purpose of this study was to analyse the impact of PBL in developing independent learning, and the learning success rate in designing lesson plans based on the new curriculum. This study will benefit for improving learning and further research. 


\section{THEORITICAL FRAMEWORK}

Problem based learning (PBL) is a student-centered instructional model/approach that uses problems as a context for students to: define their learning needs, conduct selfdirected enquiry, integrate theory and practice, and apply knowledge and skills to develop a solution to a defined problem[8].

PBL include activity 1) explore an issue, 2)make a problem statement, 3 )make list possible solution, 4) make list of action to be taken, 5) write up the solution with supporting documentation, make presentation, and submit it [8]. PBL is based on student prior knowledge and the identified gaps in that knowledge, students determine the learning issues within individual or group.

PBL emphasize the facets: Real-world challenges, Higher order thinking skills, problem-solving skills, interdisciplinary learning, skills in gathering, teamwork, communication skills, and independent learning [8].

Independent learning is a means to improve learning achievement or success of learning. Independent learning is the activity of thinking, acting and behaving students independently, without the help of a teacher or friend, to achieve the goal [10]. Independence among others, include motivational processes, modification, and settings, such as following instructions, processing information, connect new material with previous material, confident of the ability of self, can build productive work, and can build a social environment. Research shows that there is a link learning independence with learning outcomes [10]

The achievement of student learning can be considered a success. Success can involve aspects of attitudes, behavior, and intellectual. Learning success can be viewed from the aspect of attendance, preparation, curiosity, retention, attitude, talent, effort, communication, and learning outcomes [4]. The ability to make lesson plan is one of the learning success, and the learning success can be measured and categorized.

\section{RESEARCH METHOD}

This research was conducted on Biology prospective teacher at the Department of Biology Education FPMIPA UPI, that attend class of "Planning Lessons". Subjects were one class with the total number of subjects were 13 students, three males and 10 females. The course is a three-credit course that include activity of making lesson plan (LP) and implementing it in learning. This study focused on designing lesson plans with PBL. Students were asked to design LP of certain Biology material (Junior/High School) according curriculum 2013. This LP includes: core competencies, basic competency, indicators, specific learning objectives, subject matter analysis, model/approach/method, teaching and learning activities, and evaluation[9].

The research method was descriptive [6]. Instruments used include a questioner to measure the level of independence and a lesson plan rubric to measure the level of ability in designing lesson plans or learning success. The instruments were given at the end of the semester after all of the LP finished and submitted by students to the lecturer. Data on independent learning and learning success were analysed by the percentage and it is categorise das very high (> 80), high (61-80), moderate (41-60), low (21-40), and very low (<20), and then described. The Role of PBL in developing learning independence and learning success were categorized in the same way.

\section{RESULT AND ANALYSIS}

\section{A. Learning Independence and PBL}

Independent learning is the process of designing and selfmonitoring include the process of cognitive, affective, and psychomotor for completing an academic task. Learning independence under study includes 10 components [3;7]. The average result of the study to this ten component include capability of : (1) diagnosing learning needs, average: 52.5 (moderate); (2) formulate learning objectives: 52.1(moderate); (3) identify the necessary learning resources : 67.6 (high); (4) selecting and implementing learning strategies: 63.0 (high); (5) evaluate learning outcomes: 54.6 (moderate); (6) Learning initiative with or without the help of others: 78.8 (high); (7) looking at problems as challenges: 78.3 (high); (8) look for information-record and monitor: 56.5 (moderate); (9) comparing the position themselves to certain standards: 54.5 (moderate); (10) self-confidence (self-efficacy) : 69.2 (high). The average level of student independence is at high category, average: 62.7 . The average of learning independently of men $(75,7)$ and women $(68,5)$ including high catagory. In men learning independence between 65.3 to 81.1 while in women between 57.5 to 82.0. Based on the scores can be interpreted that men are slightly more independent than women (Fig.1).

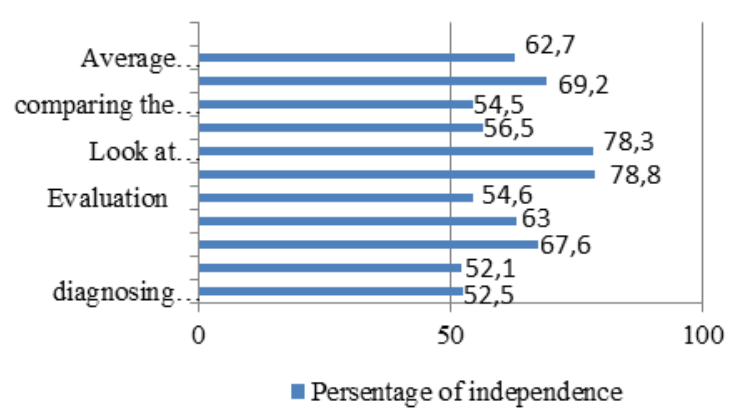

Fig. 1. Student's Learning Independence

PBL plays a crucial role in building learning independent because the steps of PBL support the component of learning independent. PBL develops: individual or group for thinking through problems, observation and monitoring of self, his own response, and comparing themselves with the position of a certain standard[1;8]. PBL can build aspects of learning independence (self-regulated learning) which is nothing but an attempt to deepen and manipulate the associative network in a particular field, and monitoring and improving the process of deepening concerned. This shows that independent learning is self-monitoring process of designing and careful review of the cognitive and affective processes in completing an academic assignment [3;7]. 


\section{B. Learning Success and PBL}

Student's learning success obtained from his ability in designing or making lesson plans (RPP), after half a semester of learning by PBL. The success of student learning in designing lesson plans is generally relatively high. Average of all lesson plan component[9] were high. Average of Determining Basic competences (KD): 78.6; making the indicator :68.1; set goals :70.6; formulated material: 71.1; determine the media : 62.5 ; formulate teaching and learning activities (KBM): 63.5; set the time: 74.3; making worksheet (LKS): 65.9; determine the source of learning: 77.8; and make an evaluation: 62.5; except in a decisive component-method/ approach/models were moderate (58). The total average ability of students to design RPP is high (68.4). Knowledge of Student about it needs to be improved. The data of RPP assessment results can be read on the figure 2 .

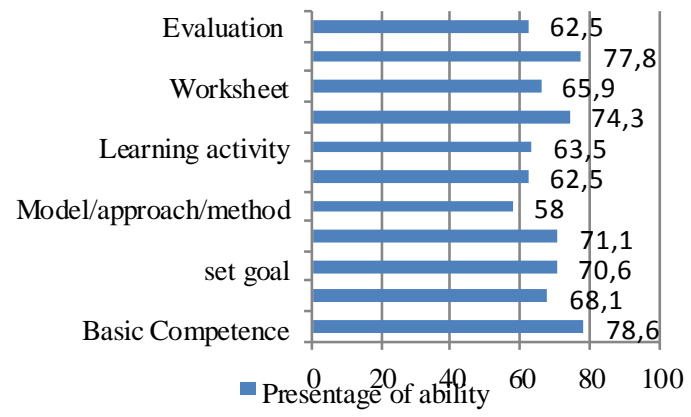

Fig. 2. Student's Ability in making Lesson Plan

As mentioned, creating lesson plans need high-level thinking skills such as problem solving and PBL facilitate this. PBL is an instructional model that involves students to be able to solve the problem according to the stages of the scientific method, learn the knowledge through problems. PBL uses real world problems as a learning context for thinking critically, skill in solve problems, as well as to acquire knowledge and essential concept of the material studied[1;2;8].

PBL facilitate student for learning independently and learning successfully because PBL has the following characteristics: (1) learning begins with a problem, (2) ensure that the problem relates to the real world of students, (3) organizing lessons around the issue, (4) provide a great responsibility to students in forming and running direct their own learning process, (5) using a small group, and (6) requires students to demonstrate what they have learned in the form of performance results $[1 ; 2 ; 8]$. Based on the above information, it seems clear that learning with PBL models initiated by the problems that can be raised by students or faculty, students deepen his knowledge of what they already know and what they need to know to suss out the problem.

PBL will benefit the learners, both high-ability learners and learners who are less capable. High-ability learners who can become a tutor for the poor performance, so that lowability learners that ability could be high. Learners who became the tutor can be further increased capabilities because tutors are required to think more broadly and more deeply $[2 ; 8]$.

\section{CONCLUSION}

PBL was instrumental in establishing the independence and efficacy of the prospective teachers. Independent learning of students in designing lesson plans through PBL is high, and the learning success of students in designing lesson plans is also quite high. Some components of learning independence relatively still lacking and needs to be improved include diagnosing needs, set goals, evaluate the results, looking for information and monitoring, as well as comparing the position with the standards. Some components of designing lesson plans that still it is difficult for students and need to be improved include formulating the indicators, objectives, teaching and learning activities, method/ approach/model and media, as well as evaluation. PBL suggested can be implemented as an alternative to learning the appropriate materials.

\section{Acknowledgement}

We are very grateful to our respondents, prospective teachers of biology in the Department of Biology Education UPI, for their cooperation in this study. We are indebted to the leadership of the Department of Biology Education which allowed us to conduct this study. We are also very grateful to our family on their enduring support.

\section{References}

[1] Lambros, A. (2004). Problem-Based Learning in Middle and High School Classrooms.Callifornia: Corwin Press.

[2] Levin, B.B., (2001). Energizing Teacher Education And Professional Development with Problem-Based Learning.Virginia : ASCD.

[3] Lowry, C. M. (2000). Supporting and Facilitating Self-Directed Learning. ERIC Digest No 93,1989-00-00

[4] [Nana Sudjana. (2009). PenilaianHasil Proses BelajarMengajar. Bandung: PT Remaja. Rosdakarya.

[5] Rahman, T. (2007). "ProfilKemampuanGenerikCalon Guru dalamMembuatLaporan Praktikum" JurnalSosiohumanitas. 9, (1), 63 77.

[6] Sugiyono. 2008. MetodePenelitianPendidikan: PendekatanKuantitatif, Kualitatif, dan R \& D. Bandung: Alfabeta.

[7] Sumarmo,U, (2004). KemandirianBelajar:Apa, Mengapa, dan Bagaimana dikembangkan pada Peserta Didik. Makalah pada Seminar Tingkat Nasional.FPMIPA UNY ;Yogyakarta Tanggal 8 Juli 2004.

[8] Tan, O.S. (2003). Problem-Based Learning Innovation. Singapore: Seng Lee Press.

[9] UPT PPL. (2013). PanduanPraktekKependidikan. Bandung: UPI

[10] Zimmerman, B. J. (2001). Theories of self-regulated learning and academic achievement: An overview and analysis. In B. J. Zimmerman \& D. H. Schunk

[11] ___ (Eds.). Self-regulated learning and academic achievement: Theoretical perspectives (2nd ed., pp. 1-37). Mahwah, NJ: Erlbaum. 
